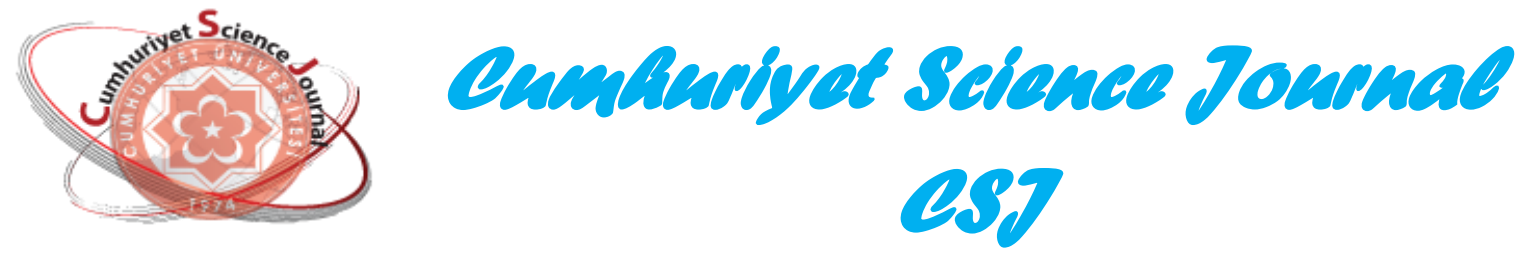

\title{
Investigation of Antibacterial Properties of Mucus and Coelomic Fluid Obtained from Eisenia Fetida
}

\author{
Ŭgur TUTAR ${ }^{1 *}$ ísa KARAMAN ${ }^{2}$ \\ ${ }^{1}$ Department of Nutrition and Dietetics, Faculty of Health Sciences, Cumhuriyet University, Sivas, TURKEY \\ ${ }^{2}$ Department of Bioengineering, Faculty of Natural Sciences and Engineering, Gaziosmanpaşa University, Tokat, TURKEY
}

Received: 14.06.2017; Accepted: 17.07.2017

http://dx.doi.org/10.17776/csj.340474

\begin{abstract}
In several researches it was found that earthworms are protected from the infective effects of many pathogen microorganisms, with which they live together, by their strong immune systems and secreted fluids; in addition, vermicompost, their coelomic fluid and mucus are effective against certain bacteria. In this study, Disk Diffusion, Minimum Inhibitory Concentration (MIC) and Minimum Bactericidal Concentration (MBC) tests were applied to determine the activities of the extracts obtained from coelom-mucus fluids of Eisenia fetida type earthworm against seven pathogenic bacteria causing diseases in plants. At the end of the study, zone diameters of the coelom-mucus fluids obtained from earthworms were measured to be between $8-54 \mathrm{~mm}$, whereas their MIC and MBC values varied between $0.06-0.5 \mathrm{mg} / \mathrm{mL}$ and $0.25-2 \mathrm{mg} / \mathrm{mL}$, respectively. The findings showed that antibacterial activity of coelom-mucus fluids obtained from E. fetida type earthworms on plant pathogens is remarkable. This study is expected to enlighten future studies investigating antimicrobial effects, structure and activity mechanisms of the isolates and extracts obtained from E. fetida and other types of earthworm.
\end{abstract}

Keywords: Eisenia fetida, coelomic fluid, mucus, antimicrobial activity

\section{Eisenia fetida'dan Elde Edilen Sölom ve Mukus Sıvılarının Antibakteriyel Özelliklerinin İncelenmesi}

Özet: Toprak solucanlarının, birçok patojen mikroorganizma ile birlikte yaşarken bunların enfektif etkilerinden güçlü immun sistemleri ve salgıladıkları sekresyonlarla korunabildikleri, ayrıca vermikompost, sölom ve mukus sıvılarının bazı patojen bakterilere karşı etkili oldukları yapılan çeşitli araştırmalarla saptanmıştır. Bu çalışmada, E. fetida türü toprak solucanlarının sölom-mukus sıvilarından elde edilen ekstraktların, bitkilerde hastalıklara neden olan yedi adet toprak kaynaklı patojen bakteriye karşı etkinliklerinin belirlenmesi amacıyla Minimum İnhibisyon Konsantrasyon (MIC) ve Minimum Bakterisidal Konsantrasyon (MBC) testleri uygulanmıştır. Çalışma sonuçlarına göre, toprak solucanlarından elde edilen sölom ve mukus sıvılarının çalışılan bakterilere karşı zon çapları 8-54 mm arasında ölçülürken, MIC değerleri 0.06-0.5 mg/mL, MBC değerleri ise 0.25-2 $\mathrm{mg} / \mathrm{mL}$ arasında bulunmuştur. Bulgular E.fetida türü toprak solucanlarından elde edilen sölom- mukus sıvılarının bitki patojenleri üzerinde antibakteriyel aktivitelerinin dikkate değer olduğunu göstermektedir. Yapılan bu çalışmanın, E. fetida'dan ve diğer toprak solucanı türlerinden elde edilecek izolat ve ekstraktların antimikrobiyal etkinliklerinin, yapılarının ve etki mekanizmalarının araştııldığı diğer çalışmalara ışık tutması beklenmektedir.

Anahtar Kelimeler: Eisenia fetida, sölom sıvısı, mukus, antimikrobiyal aktivite

\footnotetext{
* Corresponding author. Email address: ututar@cumhuriyet.edu.tr

http://dergipark.gov.tr/csj C2016 Faculty of Science, Cumhuriyet University
} 


\section{INTRODUCTION}

The negative effects of chemical pesticide applications, which are highly increased in recent years to be able to fight with plant diseases, on human and environmental health are increasing every day. For this reason, studies about the development of eco-friendly alternative plant protection methods attracts the attention of researchers. Thereby, they attempt to eliminate the negativity caused by the chemicals and their residues by developing various methods to be used in the fight against diseases and pests using substances of plant and animal origin. In this context, earthworms are considered as an important resource and scientist found that earthworms are quite effective on the development of the plants in a healthy and strong manner, on crop yield and on the improvement of soil structure. Some pot and field studies revealed that earthworms inhibit plant diseases. Researchers explained the reason of not being affected by the microorganisms, which may cause infection in many living creatures, with the strong immune system of the earthworms, and their enzymes and molecules that have antimicrobial activity. Antimicrobial substances found in the coelomic fluid, antigen binding proteins and lysozyme are mentioned as the significant elements of the immune system. The researchers reported that enzymes and proteins found in coelomic fluid, such as agglutinin, fetidin, lumbricidin and chitinase, are effective against certain microorganisms and against pests having chitin in their corpus, thus they eliminate negative effects of many disease factors and pests [1].

Mucus fluid provides protection against invasion of microorganisms by wrapping the surface of the worms like a package. The process of phagocytosis takes place under this part, in the section where natural macrophage and mononuclear phagocytes stand. Hereinafter there is the area where the humoral and cellular immune response occurs. The intrinsic response is formed in the most inner part. The mentioned sections protect the worms considerably from the infective effects of pathogens by working together $[2,3,4]$. As can be understood from these studies, earthworms may fight against many microorganisms sharing their natural living environments with the protein and enzyme character founding their structure. It can be assumed that certain extracts that will be obtained from the warms may also be effective on the microorganisms living in the same natural environment, which cause diseases on plants.

The objective of our study is to determine antimicrobial activity of mucus and coelomic fluids obtained by using various solvents, against plant pathogens that causes serious economic losses. In this way, we expect to make a contribution to the development of alternative control methods using natural potential agents obtained from earthworms, to high level future studies and to the literature.

\section{MATERIALS and METHODS}

Eisenia fetida worms that are used as rootstocks in the study were procured from a worm farm operating in Cekmeköy, Istanbul. The microorganisms Pseudomonas syringae, Xanthomonas carotae, Xanthomonas campestris, Erwinia chrysanthemi, Erwinia herbicola, Pseudomonas cepacia and Pseudomonas fluorescens bacteria were procured from the culture collection of Biology department of Gaziosmanpaşa University in Tokat/Turkey.

\subsection{The Production of Worm Castings and Vermicompost}

A pool of $1 \mathrm{~m} \times 1 \mathrm{~m}$ with $40 \mathrm{~cm}$ height was prepared for the growth of the worms. A mixture of cattle manure and kitchen waste laid down $(15 \mathrm{~cm}$ height $)$ on this pool for their nutrition and watered a few times a day in the form of sprinkling until it reaches $70 \%$ humidity. Approximately 2500 E. fetida type earthworms were placed in this worm bed. The blend of nutrients that will be given to the worms was prepared by mixing cattle manure (around $70 \%$ ) and kitchen waste (potato peelings, cabbage leaves, tea pulp, lettuce, apple peel, etc. - around $30 \%)$. It was reported in many studies that the nutrients to be given to worms should be formed by the mixtures of organic substances with 20-30 carbon-to-nitrogen ratio for both the population growth rate and the development of the worms, as well as for the quality of the vermicompost that will be obtained. In addition, some studies reported that the physical and chemical structures of the food to be given to the worms is also important; chemical 
and physical properties such as salinity, $\mathrm{pH}$, ammonia and moisture level, not only affects the nutrition of the worms, but also affect the quality of their living environment [5].

Ideal life and food environment of E. fetida is expressed as: between $15-24^{\circ} \mathrm{C}$, around $60-90 \%$ humidity, less than $0.5 \mathrm{mg} / \mathrm{g}$ and $0.5 \mathrm{mg} / \mathrm{kg}$ of ammonia and salt respectively, $\mathrm{pH} \mathrm{5-9}$ and rich in oxygen [6]. In this regard, the $\mathrm{pH}$ of the organic waste substances that will be given to the worms as nutritive was checked, their humidity and temperature were measured and the deficiencies were corrected. In order to ensure that there won't be salinity and ammonia problems, the cattle manure added to the blend was chosen among the fermented ones. The bed was moistened with light watering in daily controls in order to prevent drying on the surface. Worms particularly escape from sunlight, they live at the bottom of the bed, they migrate to the upper parts by consuming the nutrients; thus it was reported that hunger and light stress of the worms should be prevented by adding fresh nutritive [7]. Accordingly, a dark environment was provided by covering the top of the pool with cardboard and fresh nutritive was added in every 7-10 days.

Many researchers reported that the composting operation of the organic substances by the worms should take at least 90 days [6]. In addition, Sinhal et al., (2010) stated that the worms have doubled their number in 60-70 days. Accordingly, the composition period of vermicompost, which will last until transferring the worms to another bed and harvesting, has been estimated as 150 days.

\subsection{Obtaining Coelomic Fluid and Mucus from Worms}

Researchers reported that worms react against physical and chemical stress creators and stimulators, such as chemicals, low voltage electricity, ice and high temperature, by secreting coelomic fluids $[2,3,4,8,9]$. In some researches it has been observed that worms leave all coelomic fluids if the stimulation continues [9]. In our study, we attempted to gather coelomic fluids by creating stress on the worms using ethanol, methanol and chloroform solvents. In this part of the study, worms were collected from the beds and they were cleansed from organic matter by washing with tap water. In order to clean their intestines, they were transferred to containers containing only unprinted paper and kept there for 18-20 hours. Afterwards, they were washed with sterile distilled water until the substances on them were completely removed, dried with filter paper and weighted. $500 \mathrm{~g}$ of worms (around 1200 pieces) were left into beakers, each containing $400 \mathrm{ml}$ ethanol, methanol or chloroform. This method allowed to wash the worms with different solvent sand gain the mucus found on the body surface. After this stage, solvents were regained through rotary evaporator and the pure extract containing worm's coelom and mucus was obtained.

\subsection{Determination of Antimicrobial Activity}

\subsubsection{Disc Diffusion Method}

The method has been applied according to rules of "Kirby-Bauer Disk Diffusion Test Protocol". The bacteria of specific intensity were planted into the agar medium and antibiotic impregnated discs were placed on it. After a night of incubation, inhibition zone diameter around the disk was measured and the potential sensitivity level of the bacteria against the antibiotic substance was found. In the study, bacteria that were adjusted according to 0.5 McFarland $\left(10^{8} \mathrm{cfu} / \mathrm{mL}\right)$ standard were planted into Müller Hinton Agar (MHA) media using a sterile swab. Blank discs of $6 \mathrm{~mm}$ diameter were placed on the plates. For each extract, $100 \mathrm{mg} / \mathrm{ml}$ dilution was prepared using the solvent used in the extraction process. 20 microliter of the dilution was impregnated to the blank disks. Thereby, $2 \mathrm{mg}$ extract was added to each blank disk of $6 \mathrm{~mm}$ diameter. This process was applied to each extract one by one for each bacterium. At the same time sulbactam-cefoperazone and imipenem antibiotic disks were placed into the media for positive control and $20 \mu \mathrm{l}$ methanol, ethanol or chloroform impregnated disks were placed as negative control. Following 24 hours of incubation at $36.5^{\circ} \mathrm{C}$, inhibition zones around the disks were measured and recorded. 


\subsubsection{Determination of Minimum Inhibitory Concentration (MIC)}

Minimum Inhibitory Concentration (MIC) and Minimum Bactericidal Concentration (MBC) methods were used for determining in vitro antimicrobial activity of ethanol, methanol and chloroform extracts of worm's coelom and mucus fluids. Bacteriostatic activity levels of the extracts, which create a significant zone according to disk diffusion model, were identified through MIC determination [10].

Muller Hinton Broth liquid agar media was used for determining MIC values. $2 \mathrm{ml}$ of the bacterial suspension that has been prepared according to 0.5 McFarland scale were put into sterile tubes, then 2 $\mathrm{ml}$ of the extract (between $2-0.03 \mathrm{mg} / \mathrm{ml}$ ) that has been prepared via serial dilution was added. MHB was used as control. In addition, sulbactam/cefoperazone (1/1) was used as positive control, whereas the solvent used in the extraction of the active substance was used as negative control. Following 24 hours of incubation at $37^{\circ} \mathrm{C}$, the tube before the one where a visible blur was clearly observed, was recorded as the MIC value of the active substance.

\subsubsection{Determination of Minimum Bactericidal Concentration (MBC)}

MBC is the lowest concentration of the antibacterial substance that kill pathogens. MBC value shows the bactericidal activity of the antibacterial substance. While looking for the MBC value, samples taken from clear tubes (starting from the tube determined as MIC value and going back to the tube) were added to Müller Hinton Agar media with the swab. After a night of incubation, the first concentration where reproduction did not occur at the agar media was determined as the MBC value [10].

\section{RESULTS and DISCUSSION}

After approximately 30 days of the placement of the worms to the pools, numerous baby worms were counted within the stack. At the end of the 15weeks production period, the worms found in 10 $\mathrm{cmx} 10 \mathrm{~cm}$ areas, taken from 4 different section of the pool were counted. The whole worm population was estimated to be around 12.000. It has been found that population growth rate is similar to the average growth rate reported in other academic studies.

Zone diameters measured at the end of the disk diffusion test, which was conducted by applying the coelom and mucus mixture that has been obtained by treating the worms with different solvents, to plant pathogenic microorganisms are shown in Table 1, whereas MIC and MBC values are given in Table 2.

Table 1. Antibacterial activity of mucus and coelomic fluid against bacterial species tested by disc diffusion assay.

\begin{tabular}{lccc}
\hline \multicolumn{4}{c}{ Zon inhibition (mm) } \\
Bacteria & eta & cho & met \\
\hline Pseudomonas syringae & 14 & 10 & - \\
Xanthomonas carotae & 10 & - & - \\
Xanthomonas & 54 & 16 & - \\
campestris & & & \\
Erwinia herbicola & - & 8 & 11 \\
Erwinia chrysanthemi & - & - & 10 \\
Pseudomonas cepacia & 15 & - & - \\
Pseudomonas & - & - & - \\
fluorescens & \multicolumn{3}{|c}{} \\
\hline eta: ethanol extract of mucus and coelomic fluid, \\
chl:chloroform extract of mucus and coelomic fluid, \\
met: methanol extract of mucus and coelomic fluid
\end{tabular}


Table 2. Minimum inhibitory concentration (MIC) and Minimum Bactericidal Concentration (MBC) of mucus and coelomic fluid against bacterial test organisms.

\begin{tabular}{lcccccc}
\hline & \multicolumn{3}{c}{ MIC (mg/mL) } & \multicolumn{3}{c}{ MBC (mg/mL) } \\
Bacteria & eta & cho & met & eta & cho & met \\
\hline Pseudomonas syringae & 0.25 & 0.5 & - & 0.5 & 2 & - \\
Xanthomonas carotae & 0.5 & - & - & 1 & - & - \\
Xanthomonas campestris & 0.06 & 0.25 & - & 0.25 & 1 & - \\
Erwinia herbicola & - & 0.25 & 0.12 & - & 0.5 & 0.5 \\
Erwinia chrysanthemi & - & - & 0.12 & - & - & 0.25 \\
$\begin{array}{l}\text { Pseudomonas cepacia } \\
\text { Pseudomonas fluorescens }\end{array}$ & 0.06 & - & - & 0.25 & - & - \\
\hline $\begin{array}{l}\text { eta: ethanol extract of mucus and coelomic fluid, chl: chloroform extract of mucus and coelomic fluid, } \\
\text { met: methanol extract of mucus and coelomic fluid }\end{array}$ & - & & & & \\
\hline
\end{tabular}

More than 40 substances, which have cytolytic, mitogenic, proteolytic, agglutinant, haemolytic and antibacterial effects, were identified in the coelomic fluid of earthworm [11,12]. Thanks to lysine they have earthworms indicates hemolytic effects to extraneous and pathogenic substances [13].

In addition, antibacterial effects of numerous proteins, called as fetidin, lysenin, Eisenia-fetidaandrei-factor (EFAF), $\mathrm{H} 1, \quad \mathrm{H} 2, \quad \mathrm{H} 3$, coelomiccytolytic factor (CCF-1), whose molecular weights are between 40-70 kDa are discussed [14].

Milochau et al., (1997) stated that coelomic fluid of Eisenia andrei indicates strong hemolytic activity against some mammalian erythrocytes and bacteria[15]. Edwards et al., (2006) revealed that earthworms' antimicrobial secretions have suppressive effects against some soil-borne diseases with their physical, chemical and biological properties [16].

Szczech (1999) stated that against Fusarium oxysporum lycopersici fungus, which causes infection in tomato plant, the application of vermicompost to the soil showed suppressive effect in the progression of the disease [17]. The researcher has found that vermicompost, which have been sterilized by heat or disinfected with various chemicals didn't exert this effect. This fact shows that biotic factors play a significant role in the antimicrobial activity of vermicompost [16]. In a study, Edwards et al. (2006) have investigated the suppressive effect of applying different amount of vermicompost on soil-based disease factors. Researchers have also stated that vermicompost was also effective against nematodes, arthropod and insects [18].

Vasanthi et al. (2013) reported that the extract obtained from Eudrilus eugeniae earthworms indicates strong antimicrobial activity against Escherichia coli, Salmonella abony, Bacillus subtilis, Staphylocococus aureus and Klebsiella pnuemoniae bacteria and Candida albicans, Aspergillus niger, Aspergillus flavus and Penicillum notatum fungus [9].

Shobha et al. (2008) conducted a study with intestinal extract, body wall extract and coelomic fluid of Eudrilus eugeniae type earthworms and reported that the mentioned extracts have significant preventive effect on the reproduction of pathogenic plants bacteria (Xanthomonas campestris, Ralstonia solanacearum and Erwinia carotovora) and fungus (Fusarium oxysporum) [8]. 
In addition, some studies reported that a protein called "fetidin", which is also isolated from earthworms, is effective against gram positive (Bacillus megaterium) and gram negative (Aeromonas hydrophila) bacteria fetidin secreted from cholorogen makes around $75 \%$ contribution to the bactericidal activity of coelomic fluid. In addition, they damage the structure of the organisms is by connecting to the cell walls of gram negative bacteria and yeast [19].

Cho (1998) has defined an original antimicrobial peptide called "Lumbricin I", from Lumbricus rubellus. Lumbricin I indicate a broad spectrum antimicrobial effect against microorganisms without hemolysis activity [20].

Liu et al. (2004) have stated that the peptide called ECP5-1, which was isolated from coelomic fluid of Eisenia fetida in 5 steps, namely ammonium sulfate precipitation, ultrafiltration, DE52 iron exchange, sephadex D-10 column chromatography and reversed phase C-18 HPLC, had impacted bacteria in two ways [21]. First of them is penetrating into the bacteria cell and preventing the reproduction of the organism, and the other is causing death by disruptingits structure by forming gaps at the bacterial cell wall.

Lysozyme enzyme causes the death of the Gram positive bacteria by breaking $\beta-1,4$ glycoside bond found between $\mathrm{N}$-acetyl glucose amine and $\mathrm{N}$ acetyl muramic acid found in their cell wall, thus disrupting the structure of mucopolysaccharide layer. It has been reported that in case of a bacteria invasion, the amount of lysozyme enzyme found in the mucus and coelomic fluid of E. fetida can increase up to 20 times and it can show its effects at maximum level in 4-5 hours [22,23]. As a result of conducted studies, it has been reported that the substances isolated from earthworms, such as catalase, superoxide dismutase, choline esterase, purine, choline, cholesterol, vitamin B, succinic acid and tyrosine can be mentioned among the substances that play a role in antimicrobial activity.

In this study, Disc Diffusion, Minimum Inhibitory Concentration (MIC) and Minimum Bactericidal Concentration (MBC) tests were applied for revealing the activities of the extracts obtained from coelom-mucus fluids of Eisenia fetida type earthworm against ten soil-borne pathogenic bacteria causing diseases in plants. According to the outcomes of the study, coelom-mucus fluids obtained from earthworms have formed an inhibition zone between $8-54 \mathrm{~mm}$ against of the tested bacteria. MIC values of the extracts against these bacteria were found to be between 0.06-0.5 $\mathrm{mg} / \mathrm{mL}$ and MBC values were between $0.25-2$ $\mathrm{mg} / \mathrm{mL}$. The findings showed that coelom and mucus fluids, extracted with ethanol, methanol or chloroform, had the potential of preventing the reproduction of the bacteria that were used in the research. The result that we obtained from the study are in line with the results of the previous ones.

Through this study, it has been determined that earthworms' immune system components, which allow them to survive against infections, may also be effective against many soil-based plant pathogen bacteria and fungus found in their life area.

In the future, pot and field experiments of the isolates and extracts that will be obtained from Eisenia fetida that we have used in our study, as well as from other earthworm species should be performed and the researches about the control of the diseases that cause significant production and quality losses should be extended.

\section{CONCLUSION}

The results of our study are expected to make contributions to future studies that investigate the possibility of using the substances obtained from different earthworms and from their derivatives on alternative medicine and agriculture, as well as to the studies that will aim to determine antimicrobial activities, structures and impact mechanisms of earthworms. 


\section{REFERENCES}

[1]. Wang C, Sun Z, Zheng D (2006). Research advance in antibacterial immunity ecology. The Journal of Applied Ecology, 17: 525-529.

[2]. Bruke JM (1974). An ultra structural analysis of the cuticle, epiderm is and esophage alepithelium of Eisenia foetida (Oligochaeta). J Morphol, 142: 301-320.

[3]. Anderson WA, Weissman A, Eill RA (1976). Cyto differentiation during sperm iogenesis in Lumbricus terrestris. J Cell Biol, 32: 11-26.

[4]. Xiao Y, Lu Y, Qui J (2002). The ultrastructural of integumentary system in Pheretima Californica (Oligochaeta: Megascolecidae). Journal of Shangai Teachers University ( Natural Science), 31: 79-85.

[5]. Hand P, Hayes WA, Frankland JC (1988). Vermicomposting of cowslurry. Pedobiologia, 31: 199-209.

[6]. Edwards CA (1988). Break down of animal, vegetable and industrial organic wastes by earthworms. SPB Academic Publ.Co., 21-31.

[7]. Sinhal RJ, Agarwal S, Chauhan K, Chandran V, Soni BK (2010). Vermiculture Technology: Reviving the Dreams of Sir Charles Darwin for Scientific Use of Earthworms in Sustainable Development Programs. Technology and Investment, 1: 155-172.

[8]. Shobha SV, Kale RD (2008). Invitro studies on control of soil- borne plant pathogens by earthworm $E$. eugeniae exudates. http://www.eco-web.com/edi/080106.html.

[9]. Vasanthi K, Chairman K, Ranjit Singh AJA (2013). Antimicrobial activity of earthworm (Eudrilus eugeniae) paste. African Journal of Environmental Science and Technology, 7:789-793.

[10].Clinical and Laboratory Standards Institute (CLSI) (2012). Performance Standards for Antimicrobial Susceptibility Testing; Standard-Eleventh Edition (M02-A11).

[11].Kauschke E, Pagliara P, Stabili L, Cooper EL (1997). Characterization of proteolytic activity in coelomicfluid. ZoolSci, 12: 225230.
[12].Bilej M, Baetselier PD, Dijck EV, Stijlemans B, Colıge A, Beschın A (2001). Distinc carbonhydrate recognition domains of intervertabrate defense moleculer ecognize Gram negative and Gram positive bacteria. J Biol Chem, 276: 45840-45847.

[13].Engelmann P, Kiss J, Palinkas L, Cooper EL (2004). Earthworm leukocytes kill HeLa, Hep-2, PC-12 and PA-317 cells in vitro. J Biochem Biophys Methods, 61: 215-227.

[14].Koenig S, Wagner F, Kauschke E, Katlinic JP, Cooper EL, Eue I (2003). Mass spectrometric analyses of CL39, CL41 and H1, H2, H3 confirm idendity with fetidin and lysenin produced by earthworm leukocytes. Dev Comp Immunol, 28: 701-711.

[15].Milochau $A$, Lassègues $M$, Valembois $P$ (1997). Purification, characterization and activities of two hemolytic and antibacterial proteins from coelomicfluid of the annelid Eisenia fetida and rei. Bio chim Biophys Acta,1337:123-132.

[16].Edwards CA, Arancon NQ, Greyta, S (2006). Effects of Vermciompost Teas on Plant Growth and Diseases. Biocycle, 47: 28-31.

[17].Szczech MM (1999). Suppressiveness of Vermicompost against Fusarium Wilt of Tomato. J Phytopathol, 147:155-161.

[18].Arancon NQ, Galvis PA, Edwards CA (2005). Suppression of insect pest population sand insect damage to plants by vermicomposts. Bioresource Technol, 96: 1137-1142.

[19].Pan W, Liu X, Ge F, Zheng T (2003). Reconfirmation of antimicrobial activity in the coelomicfluid of the earthworm Eisenia fetida and rei by colorimetric assay. J Biosci, 28: 723-731.

[20].Cho JH, Park CB, Yoon YG (1998). Lumbricin I, a novel proline-richanti microbial peptide from the earthworm: purification, cDNA cloning and molecular characterization. Biochım Biophys Acta, 1408: 67-76.

[21].Liu YQ, Sun ZJ, Wang C, Li SJ, Liu YZ (2004). Purification of a novel antibacterial short peptide in earthworm Eisenia foetida. Acta Biochim Biophys Sin,36:297-302. 
[22].Hirigoyenberry F, Lassalle F, Lassegues M (1990). Antibacterial activity of Eisinia fetida and reico elomicfluid: transcription and translation regulation of lysozyme and protein sevidenced after bacterial infestation. Comp Biochem Physiol, 95: 71-75.
[23].Kohlerova P, Beschın A, Silerova M, Baetselier PD, Bilej M (2004). Effect of experimental microbial challenge on the expression of defense molecules in Eisenia foetida earthworm. Dev Comp Immunol, 28: 701-711. 